\title{
THROMBOCYTOPENIC PURPURA IN THE NEWBORN
}

\author{
BY \\ M. BRENDA MORRIS \\ From Whittington Hospital, London
}

(RECEIVED FOR PUBLICATION OCTOBER 10, 1953)

Thrombocytopenic purpura in the newborn is an uncommon condition which has, however, been well reported. The literature has been reviewed by Robson and Walker (1951) who found 60 cases and added three of their own. These included 11 in which no platelet count was reported, but in which they considered that other evidence was adequate for their inclusion in the series, and two (Guttfreund, 1933; Lightwood, 1931) in which the condition did not present until four months and five weeks after birth respectively.

They classified these 63 cases as follows:

THROMBOCYTOPENIA IN 63 INFANTS

\begin{tabular}{ll|l}
\hline Group I & $\begin{array}{c}\text { Infants born of mothers with thrombocytopenia } \\
\text { purpura } \\
\text { (a) Idiopathic (essential) including mothers who } \\
\text { had had splenectomy. } \\
\text { (b) Secondary to drugs, toxins etc., or from } \\
\text { cause unknown. }\end{array}$ \\
\hline Group II & Infants born of normal mothers \\
\hline
\end{tabular}

Twenty-seven cases have since been described (Åkerrén and Reinand, 1950; Boyette, 1951; Dobbs, 1950; Epstein, Lozner, Cobbey and Davidson, 1950; Gruber, Redner and Kogut 1951; Hauser, 1948; LaDriere, 1951; Litchfield, Sternberg and Zweifler, 1950; Randak and Danforth, 1951; Saltzman, 1949; Shipton, 1950 a and b; Weill and Grappe, 1951) all of which fall into one of these groups. It is of interest that six of these had thrombocytopenia (platelets less than 100,000/c.mm.) with no haemorrhagic manifestations.

Three further examples of this condition are reported one of which shows features in the mother which have not been previously described.

\section{Case Reports}

Platelet counts were performed by the indirect method of Dacie (1950).

Case 1.-Baby K., the first, a boy, was born at full term by forceps delivery. He had blue asphyxia at birth. Lobeline and 'synkavit' were given three hours after birth. Numerous petechial haemorrhages and ecchymoses which progressed, were noted. The spleen was not palpable. The infant vomited fresh blood and oozing continued from the injection sites. Six hours after birth biparietal cephalhaematomata began to appear and the cry became whining. The fontanelle was flat.

Haemoglobin was $105 \%$, and practically no platelets were seen on a film.

Seven to ten hours after birth the infant had haematemesis and melaena and at $\mathbf{1 0}$ hours a transfusion of $\mathbf{9 0}$ $\mathrm{ml}$. stored blood was given via the umbilical vein. At the end of the transfusion the fontanelle was noted to be full.

Twenty-hours after birth the infant was lying in the position of opisthotonus, but was not rigid. The fontanelle was full. A little melaena was seen but there were no other haemorrhagic manifestations after transfusion.

On lumbar puncture, $10 \mathrm{ml}$. of heavily bloodstained cerebrospinal fluid under increased pressure was withdrawn.

Haemoglobin was $150 \%$, and platelets $18,000 /$ c.mm.

On the sixth day the platelets had risen to $27,000 / \mathrm{c} . \mathrm{mm}$. and on the fifteenth day to $280,000 /$ c.mm.

The baby made a gradual but satisfactory recovery and on the tenth day was behaving normally. He was discharged on the eighteenth day, breast fed and complemented.

At 3 months of age he was a normal baby, and a blood film showed normal platelets.

Baby K's. mother was aged 26, perfectly normal, and had had an uneventful pregnancy. Her platelet count on the second day after delivery was $300,000 / \mathrm{c} . \mathrm{mm}$., and on the fourth day after delivery, $240,000 /$ c.mm.

Case 2.-Baby H., a third baby and a girl, was born at full term by normal delivery (birth weight, $6 \mathrm{lb} .6 \mathrm{oz}$.). A generalized petechial eruption developed over the trunk two hours after delivery. The spleen was not felt. The baby remained well and no other haemorrhagic manifestations occurred. She was breast fed.

On the first day platelets were $20,000 / \mathrm{c} . \mathrm{mm}$., and on the tenth day, $16,000 /$ c.mm.

On the twenty-fourth day her platelets were less than $5,000 / \mathrm{c} . \mathrm{mm}$., on the thirty-fifth day less than $40,000 /$ c.mm., and in the twelfth week, $120,000 / \mathrm{c} . \mathrm{mm}$.

The mother of Baby $\mathrm{H}$. was aged 22. Her pregnancy and puerperium were uneventful. After the delivery of this baby it became known that she had had a splenectomy for chronic idiopathic thrombocytopenic purpura at the age of 14. She had had many haemorrhagic episodes between the ages of 9 and 14 years and had severe 
menorrhagia from the time of the menarche. Her platelet counts before operation were about 20,000/c.mm. Since splenectomy she has been quite free of purpura and her menses have been normal. Unfortunately her platelet counts between splenectomy and this delivery are not available.

Her first child, a boy, aged 5 years, was circumcised at age 36 hours and required blood transfusion. No further information is available. He has been normal since.

The second child, a girl aged 3 years is normal.

The mother's platelets on the day of delivery were $150,000 /$ c.mm.; on the fifth day after delivery, $700,000 /$ c.mm.; on the fourteenth day after delivery, $60,000 / \mathrm{c} . \mathrm{mm}$., on the twenty-fourth day after delivery, 120,000/c.mm.; on the forty-first day after delivery, $215,000 / \mathrm{c} . \mathrm{mm}$.

Case 3.-Baby M., a second baby, a girl, was born at full term after a normal delivery (birth weight $6 \mathrm{lb} .14 \mathrm{oz}$.). A generalized petechial rash was noticed one hour after birth. The spleen was not felt. The baby remained well and no other haemorrhagic manifestations occurred. She was breast fed.

On the first day platelets were $15,000 / \mathrm{c} . \mathrm{mm}$. and on the fourteenth day, $50,000 / \mathrm{c} . \mathrm{mm}$. At follow-up in the fifth week the platelets were $140,000 / \mathrm{c} . \mathrm{mm}$.

The mother of Baby M. was aged 18, a Cypriot, in England for one year. Her past history was normal in all respects, and her pregnancy and puerperium uneventful.

Her first child, a girl, aged 14 months, was born in Cyprus, and the mother thought that the child had a petechial rash at birth. At 14 months this child's platelets were $240,000 / \mathrm{c} . \mathrm{mm}$., and she was physically normal.

The mother's blood count on the day of delivery gave: platelets, 50,000/c.mm.; Hb, $104 \%$, red cells $5 \mathrm{~m}$. per c.mm., leucocytes $10,400 /$ c.mm. On physical examination nothing abnormal was found. On the fifth day after delivery platelets were $160,000 / \mathrm{c} . \mathrm{mm}$., on the fourteenth day after delivery $200,000 /$ c.mm., and five weeks after delivery $226,000 /$ c.mm.

Symptomless thrombocytopenia associated with delivery, as in the mother of Case 3, has not been previously reported. The platelet count had returned to normal by the eighth day and remained so five weeks after delivery. There was no history of any haemorrhagic manifestation in the past, of administration of drugs, or of any illness which might have caused thrombocytopenia.

There is little information available on the normal platelet counts during pregnancy and after delivery and this information is conflicting (Whitby and Britton, 1950; Shipton, 1950a) although changes in the platelet counts in relation to the menstrual cycle are known to occur (Goldburg and Gouley, 1940; Minot, 1936; Pohle, 1939).

\section{Discussion}

There have now been 80 infants reported in whom platelet counts are available; of these 63 have recovered, presumably completely, although in many of the earlier reports, summarized by Robson and Walker (1951), follow-up has not been extensive and serial platelet counts have not been recorded.
Of the 30 cases recently described, 26 recovered. Twenty-four of these had serial platelet counts. Fourteen were followed for over one month, six for over three months, one for a year, and one for two years. All remained normal.

Splenectomy has been performed on two infants, one at 14 hours after birth (Gruber, Redner and Kobut, 1951) and one at 9 days of age (Bluestone and Maslow, 1949). Both platelet counts returned to normal but the first infant died at 30 days of intercurrent infection and there was no long-term followup on the second.

Seventeen of the 80 infants died. Eleven died from haemorrhage; nine within eight days of birth, one at four weeks and one (Hauser, 1948) at nine months of age. The remaining six died from other causes, one (Landolt, 1948) when the platelet count had already returned to normal.

Thrombocytopenia in the newborn resolves spontaneously, usually in one to three weeks, although it occasionally lasts several months. Fatal haemorrhage, uncontrolled by blood transfusion, may occur while the platelet count is low. The only case in which the condition has continued for longer than four and a half months is that described by Hauser (1948) in which the infant died of haemorrhage at 9 months of age. This case was complicated by severe sepsis and leucopenia which may have had some bearing on the outcome. The mother had thrombocytopenic purpura, probably of the chronic idiopathic type. The infant's platelet count was $100,600 / \mathrm{c} . \mathrm{mm}$. On the eighth day, but symptoms did not appear until the age of 6 weeks. From then until death he had recurrent haemorrhage, with finally no platelets in the peripheral blood. Repeated blood transfusions were of no avail. This is the only infant reported in whom the illness has pursued a prolonged course which might suggest the chronic type of idiopathic thrombocytopenic purpura described by Stefanini and Dameshek (1953).

\section{Conclusion}

It appears that, with possible very rare exceptions, thrombocytopenia in the newborn infant, irrespective of the state of the mother, is a self-limiting condition. In the majority complete recovery may be expected. There is a mortality of about $14 \%$ from haemorrhage while the platelet count is low.

Thrombocytopenic purpura of the newborn, although it may be due to the passage of some thrombocytopenia-inducing agent from the maternal to the foetal circulation (Epstein et al. 1950), does not progress to the chronic type of idiopathic thrombocytopenic purpura which occurs in children and young adults. Conversely it appears from the 
fact that thrombocytopenia in the newborn recovers that chronic idiopathic thrombocytopenic purpura is not congenital.

\section{Summary}

Three further cases of thrombocytopenic purpura in the newborn are described.

In one of these the mother had a symptomless thrombocytopenia which was discovered on the day after delivery and which lasted less than a week.

The literature has been briefly reviewed and it is concluded that thrombocytopenia of the newborn is a self-limiting condition distinct from chronic idiopathic thrombocytopenic purpura.

I wish to thank Dr. Simon Yudkin for much helpful advice and criticism in preparing this paper; Professor D. M. Dunlop, Miss K. M. Harding, Mr. J. M. Scott, and Dr. Simon Yudkin for permission to publish these cases; and Dr. M. C. Simpson and Dr. C. F. Stephenson, of the Pathological Laboratory, for the haematological investigations.
REFERENCES

Åkerrén, Y. and Reinand, T. (1950). Acta med. scand., Suppl. 246, p. 281.

Bluestone, S. S, and Maslow, H. L. (1949). Pediatrics, 4, 620.

Boyette, D. P. (1951). Sth. med. J. Bgham, Ala., 44, 70

Dacie, J. V. (1950). Practical Haematoiogy. London.

Dobbs, R. H. (1950). Proc. roy. Soc. Med., 43, 832.

Epstein, R. D., Lozner, E. L., Cobbey, T. S. and Davidson, C. S. (1950). Amer. J. Med., 9, 44.

Goldburgh, H. L. and Gouley, B. A. (1940). Amer. J. med. Sci., 200, 499.

Gruber S. Redner, B and Kogut, B. (1951) N.Y. St. J. Med., 51, 649.

Guttfreund, A. (1933). Mschr. kinderheilk., 55, 436.

Hauser, F. (1948). Ann. paediat., Basel, 171, 86.

LaDriere, R. J. (1951). Sth. med. J. Bgham, Ala., 44, 355

Landolt, R. F. (1948). Helv. paediat. Acta, 3, 3 .

Lightwood, R. C. (1931). Proc. roy. Soc. Med. 25, 138.

Litchfield, H. R., Sternberg, S. D. and Zweifler, B. M. (1950). J. Pediat. 37, 94.

Minot, G. R. (1936). Amer. J. med. Sci., 192, 445.

Pohle, F. J. (1939). Ibid., 197, 40.

Randak, E. F. and Danforth, D. N. (1951). Quart. Bull. Northw. Univ. med. Sch., 25, 199 .

Robson, H. N. and Walker, C. H. M. (1951). Archives of Disease in Childhood, 26, 175 .

Saltzman, G. F. (1949). Acta med. scand. 133, 221.

Shipton. E. A. (1950a). Med. J. Aust., 1, 428.

- (1950b). Ibid., 2, 512 .

Stefanini, D. and Dameshek, W. (1953). Lancet, 2, 209.

Weill, G. and Grappe, J. (1951). Bull. Féd. Soc. Gynéc. Obstét. franc., 3, 795 .

Whitby, L. E. H. and Britton C. J. C. (1950). Disorders of the Blood, 6 th ed. London. 